\title{
ЗАБЕЗПЕЧЕННЯ ГНУЧКОСТІ СИСТЕМИ ГОСПОДАРЮВАННЯ ЗАЛІЗОРУДНОГО ПІДПРИЕМСТВА ЗА УМОВ НЕСТАБІЛЬНОСТІ ПАРАМЕТРІВ ЙОГО РИНКОВОГО ПРОСТОРУ
}

\author{
Куліш Олександр Алімович \\ Україна, Кривий Ріг \\ здобувач кафедри економіки, організачії та управління підприємствами \\ Криворізький начіональний університет
}

DOI: https://doi.org/10.31435/rsglobal_ijite/31032019/6376

\section{ARTICLE INFO}

Received 20 January 2019

Accepted 22 March 2019

Published 31 March 2019

\section{KEYWORDS}

flexibility,

system of management,

life cycle of goods,

market space,

monitoring system,

iron ore enterprise.

\begin{abstract}
In crisis conditions of entrepreneurial activity and in the conditions of instability of the market environment, the issue of providing flexibility to the iron and steel enterprises management system becomes of paramount importance in order to optimize their production programs and maximize profitability. The article generates a generalized sequence of phases of the life cycle of iron ore production for specific periods of its operation in certain sectors of the market space. The phases of the life cycle of iron ore products are planned, which are planned to be implemented on priority and, to some extent, unpredictable sectors of the market space.

The conceptual provisions of the system of monitoring the situation in the strategic zones of management of the iron ore enterprise have been developed, which allows solving the cardinal issues related to long-term forecasting taking into account adjustment of strategic goals and ways of their achievement in the field of modernization, technical re-equipment, reconstruction, reengineering, reorganization, reforming, restructuring of the iron ore enterprise.
\end{abstract}

Citation: Куліш О. А. (2019) Zabezpechennia Hnuchkosti Systemy Hospodariuvannia Zalizorudnoho Pidpryiemstva za Umov Nestabilnosti Parametriv Yoho Rynkovoho Prostoru. International Journal of Innovative Technologies in Economy. 2(22). doi: 10.31435/rsglobal_ijite/31032019/6376

Copyright: (C) 2019 Куліш О. А. This is an open-access article distributed under the terms of the Creative Commons Attribution License (CC BY). The use, distribution or reproduction in other forums is permitted, provided the original author(s) or licensor are credited and that the original publication in this journal is cited, in accordance with accepted academic practice. No use, distribution or reproduction is permitted which does not comply with these terms.

Виклад основного матеріалу дослідження. На різних етапах розвитку в залежності від зовнішнього середовища в рамках довгострокового планування можуть бути поставлені різні завдання. Зокрема, коли перед підприємством стоїть завдання виживання, тобто встановлення балансу активів залізорудного підприємства, обсягів виробленої продукції і витрат на іiі виробництво та реалізацію і підвищення на цій основі конкурентоспроможності продукції, що виробляється. За цих умов одним із важливих моментів є приведення обсягів виробництва продукції залізорудного підприємства у відповідність 3 його потужностями, де, як правило, виникає необхідність в одночасній їх модернізації з метою забезпечення збалансованості реалізації та отримання прибутку, з одного боку, активів і інвестицій з іншого. Отже, в сучасних умовах постійних трансформацій світової економіки, для залізорудних підприємств особливо важливим $\epsilon$ реалістичність довгострокового планування, яке наочно оцінює потреби залізорудного підприємства та наявність потужностей (активи залізорудного підприємства), а також фінансові завдання і результати інвестування коштів, спрямованих на забезпечення гнучкого розвитку системи господарювання підприємства за умов мінливості параметрів ринкового простору. 
Мета дослідження полягає у поглибленні теоретико-методологічних підходів моніторингу ринкових секторів гнучкого управління підприємством як одиниці аналізу та прогнозування прогресивного розвитку залізорудного підприємства.

В теорії гнучкого розвитку залізорудного підприємства інтерес до концепції життєвого циклу його продукції проявляється в зростанні обсягів іiі реалізації на пріоритетних секторах ринкового простору i, відповідно, скорочення життєвого циклу продукції в неперспективних секторах ринкового простору, де спостерігаються або ж прогнозуються тенденції до зниження рівня ефективності результатів виробничо-господарської діяльності підприємства. При цьому, принципи раціонального використання ресурсної бази залізорудного підприємства $€$ домінуючими у вирішенні завдань, спрямованих на забезпечення необхідного рівня гнучкості його виробничо-економічної системи в умовах нестабільності параметрів його ринку залізорудної продукції, обумовленої невизначеністю та конфліктністю розвитку процесів світової економіки [1].

За інших рівних умов від змін в термінах виробництва й реалізації залізорудної продукції (тривалості життєвого циклу залізорудної продукції) будуть залежати оптимальні обсяги певних видів залізорудної продукції (що різняться за собівартістю, якістю, ціною і т. ін.), які перебувають під впливом стадій розробки і впровадження інновацій щодо оновлення виробничих процесів. Разом 3 тим, при більшій тривалості життєвого циклу залізорудної продукції у підприємства $є$ можливість ії різновидів освоювати в майбутньому i, навпаки менша тривалість життєвого циклу продукції обумовлює застосування більш широкої іiі диверсифікації відносно як пріоритетних, так і певною мірою неперспективних секторів ринкового простору підприємства.

Одним із основних завдань теорії гнучкості управління залізорудним підприємством $€$ концептуальний опис початкових і кінцевих періодів кардинальних змін в умовах його функціонування на секторах цільового ринку, який доцільно здійснювати на підставі класичного подання ймовірнісного графіку життєвого циклу виробництва i реалізації залізорудної продукції (мається на увазі продукція, яка випускається і реалізується при всіх інших рівних умовах), а також певної аналітичної обробки функціональної залежності фаз життєвого циклу продукції в часі для конкретних періодів присутності підприємства на окремих секторах ринкового простору.

Сформуємо узагальнену послідовність фаз життєвого циклу продукції залізорудного підприємства для конкретних періодів його функціонування на окремих секторах ринкового простору. Фази життєвого циклу залізорудної продукції, що планується для реалізації як на пріоритетних, так і певною мірою неперспективних секторах ринкового простору підприємства можна представити таким чином (рис. 1):

1) розробка, виробництво та виведення продукції на ринок - освоєння привабливого сектору ринкового простору (фаза «Освоєння»);

2) формування меж беззбитковості реалізації продукції на окремих секторах ринкового простору (фаза «Зростання»);

3) середини життєвих циклів продукції на окремих секторах ринкового простору (фаза «Зрілості та насиченості»);

4) періоди початку змін умов для виробництва і реалізації залізорудної продукції під впливом зміни параметрів секторів цільового ринку підприємства - освоєння оновленої технології, продукції тощо (фаза «Оновлення»);

5) завершення процесу виробництва продукції, як завідомо неперспективної для реалізації в цільових секторах ринкового простору підприємства (фаза «Завершення»).

Точність оцінювання періодів фаз дозволяє прогнозувати їх циклічність, своєчасність переходу на виробництво оновленої залізорудної продукції під параметри секторів ринкового простору, що забезпечує зниження ступеню ризику та необхідний рівень гнучкості розвитку залізорудного підприємства.

Таким чином, на підгрунті візуально-аналітичного аналізу рис. 1 здійснюється опис та оцінювання різних фаз життєвого циклу залізорудної продукції, що планується для реалізації як на пріоритетних, так i певною мірою неперспективних секторах ринкового простору підприємства. Зазначене надає можливість на основі раціонально обгрунтованої системи виробничо-економічних показників діяльності підприємства на доступних до освоєння та 
реально привабливих (захищених від конкуренції, сформований позитивний імідж, достатня впевненість в ефективності функціонування на перспективу) секторах його ринкового середовища [2] підійти до вирішення задачі формування ключових критеріїв для прогнозування й оцінювання гнучкості функціонування залізорудного підприємства за умов нестабільності параметрів його ринкового простору. У ці періоди велике значення має збалансованість витрат та їх відносне зниження. Разом 3 тим, слід враховувати, що з ростом числа економічних показників змінюється і структура економіки. За цих умов завдання виживання все більше перетворюється в напрямок стратегії «ринок-продукт» і посилюється значення матриць планування стратегічних зон господарювання підприємства.

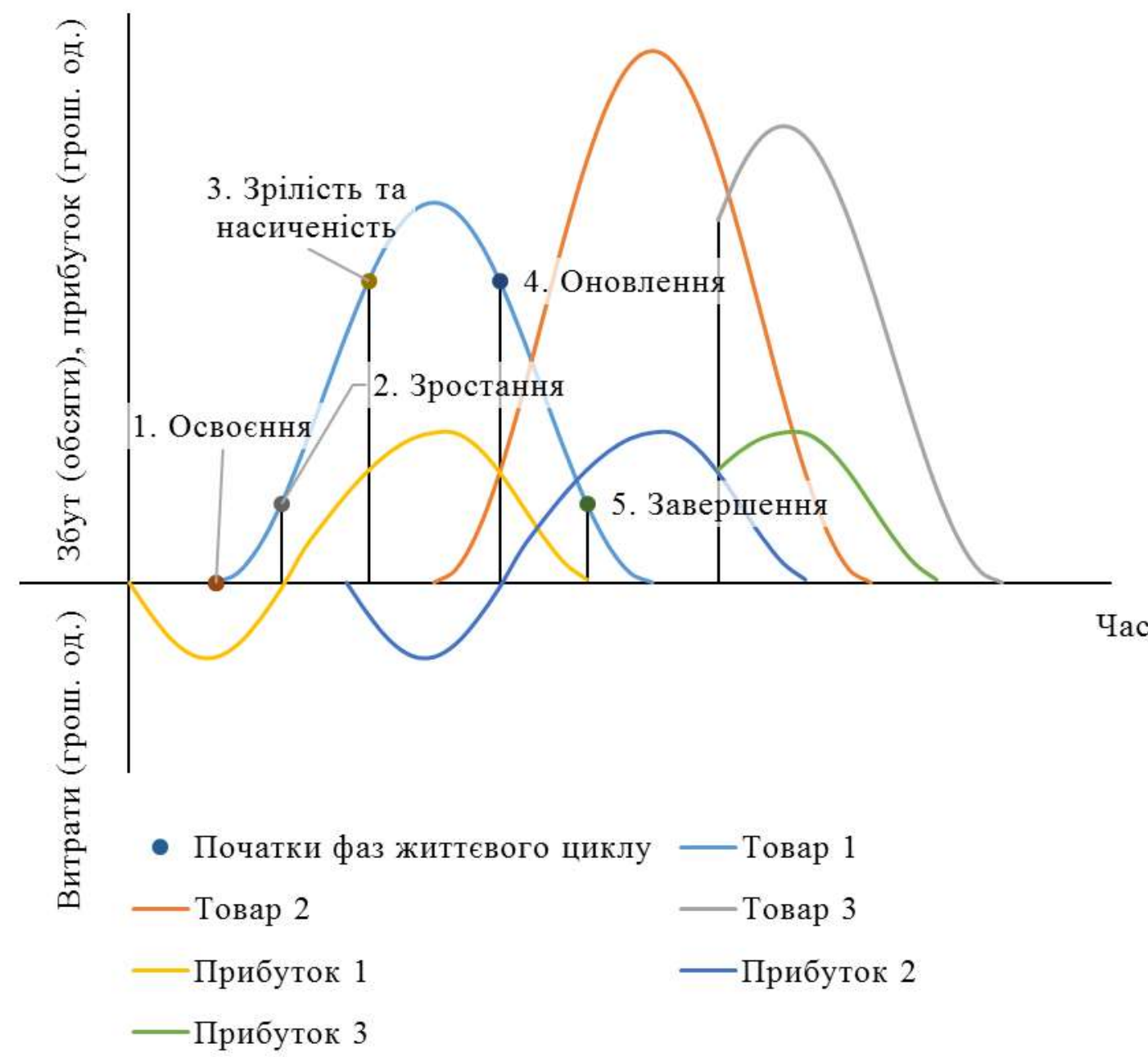

Рис. 1. Фази жситтєвого ииклу залізорудної продукиії, щуо планується для реалізації як на пріоритетних, так і певною мірою неперспективних секторах ринкового простору підприємства

Опис основних фаз життєвого циклу продукції залізорудного підприємства в часі щодо конкретних періодів його функціонування на окремих секторах ринкового простору у контексті вирішення задачі гнучкого розвитку підприємства за умов постійних трансформацій світового ринкового простору обумовлює необхідність виокремлення ринкового сектору гнучкого управління підприємством (РСГУП), як одиниці аналізу та прогнозування (табл. 1) - зони стратегічного реагування системи господарювання (ЗСРСГ) залізорудного підприємства на нестабільність параметрів його ринкового простору.

При цьому, достовірність аналізу та прогнозування результатів виробничогосподарської діяльності залізорудного підприємства багато в чому залежить від таких властивостей РСГУП, як: відносна стабільність, прозорість і простота. 3 іншого боку необхідною умовою $є$ отримання правдивої інформації щодо виробничо-економічних $\mathrm{i}$ 
фінансових показників діяльності підприємства у межах РСГУП, що забезпечує РСГУП достатню міру достовірності носія тенденцій і закономірностей щодо задоволення основних вимог критеріям оцінювання його привабливості (табл. 1):

- доступність до освоєння існуючих і нових ринкових секторів;

- конкурентоспроможність підприємства в окремих секторах ринкового простору підприємства;

- сформованість позитивного іміджу в ринковому просторі в цілому; підприємства.

- ефективність функціонування на перспективу в окремих секторах ринкового простору

Таблиця 1. Матриця моніторингу ринкових секторів гнучкого управління підприємством (РСГУП) як одиниці аналізу та прогнозування - зони стратегічного реагування системи господарювання (ЗСРСГ) залізорудного підприємства

\begin{tabular}{|c|c|c|c|c|c|c|}
\hline \multirow[b]{2}{*}{$\begin{array}{c}\text { Критерії привабливості } \\
\text { ринкових секторів } \\
\text { гнучкого управління } \\
\text { підприємством }\end{array}$} & \multirow[b]{2}{*}{ РСГУП } & \multicolumn{5}{|c|}{ Фази життєвого циклу РСГУП* } \\
\hline & & 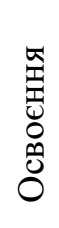 & 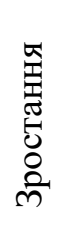 & 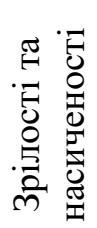 & 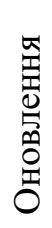 & 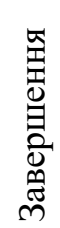 \\
\hline \multirow{5}{*}{ 1. Доступність до освоєння } & РСГУП & & & & & \\
\hline & РСГУП 2 & & & & & \\
\hline & РСГУП 3 & & & & & \\
\hline & $\ldots$ & & & & & \\
\hline & РСГУП & & & & & \\
\hline \multirow{5}{*}{$\begin{array}{l}\text { 2. Конкуренто- } \\
\text { спроможність }\end{array}$} & РСГУП & & & & & \\
\hline & РСГУП 2 & & & & & \\
\hline & РСГУП & & & & & \\
\hline & $\ldots$ & & & & & \\
\hline & РСГУП & & & & & \\
\hline \multirow{5}{*}{$\begin{array}{l}\text { 3. Сформованість } \\
\text { позитивного іміджу }\end{array}$} & РСГУП 1 & & & & & \\
\hline & РСГУП 2 & & & & & \\
\hline & РСГУП & & & & & \\
\hline & .. & & & & & \\
\hline & РСГУП & & & & & \\
\hline \multirow{5}{*}{$\begin{array}{c}\text { 4. Ефективність } \\
\text { функціонування на } \\
\text { перспективу }\end{array}$} & РСГУП & & & & & \\
\hline & РСГУП 2 & & & & & \\
\hline & РСГУП & & & & & \\
\hline & $\ldots$ & & & & & \\
\hline & РСГУП & & & & & \\
\hline
\end{tabular}

Примітка: * до таблиці заносяться оцінки рівня виконання основних критеріїв. 
Отже, концепція одиниці аналізу та прогнозування РСГУП в моделюванні тенденцій процесу гнучкого розвитку залізорудного підприємства базується на фазах життєвого циклу продукції та надає можливість оцінити ситуації, що складаються в його зонах господарювання за умов нестабільності параметрів ринкового простору й мінливості чинників навколишнього середовища. Моніторинг ситуацій в стратегічних зонах господарювання залізорудного підприємства (СЗГП) допомагає з'ясувати складні явища і що їх викликає, звести не пов'язані на перший погляд один з одним процеси до їх зрозумілих тенденцій і закономірностей, а також прийняти рішення стосовно заходів стратегічного реагування системи господарювання по конкретним ситуаціям в РСГУП (рис. 2) в майбутньому та визначитися 3 необхідними ресурсами (не в останню чергу з кадровими) [3] як на поточний період, так і перспективу.

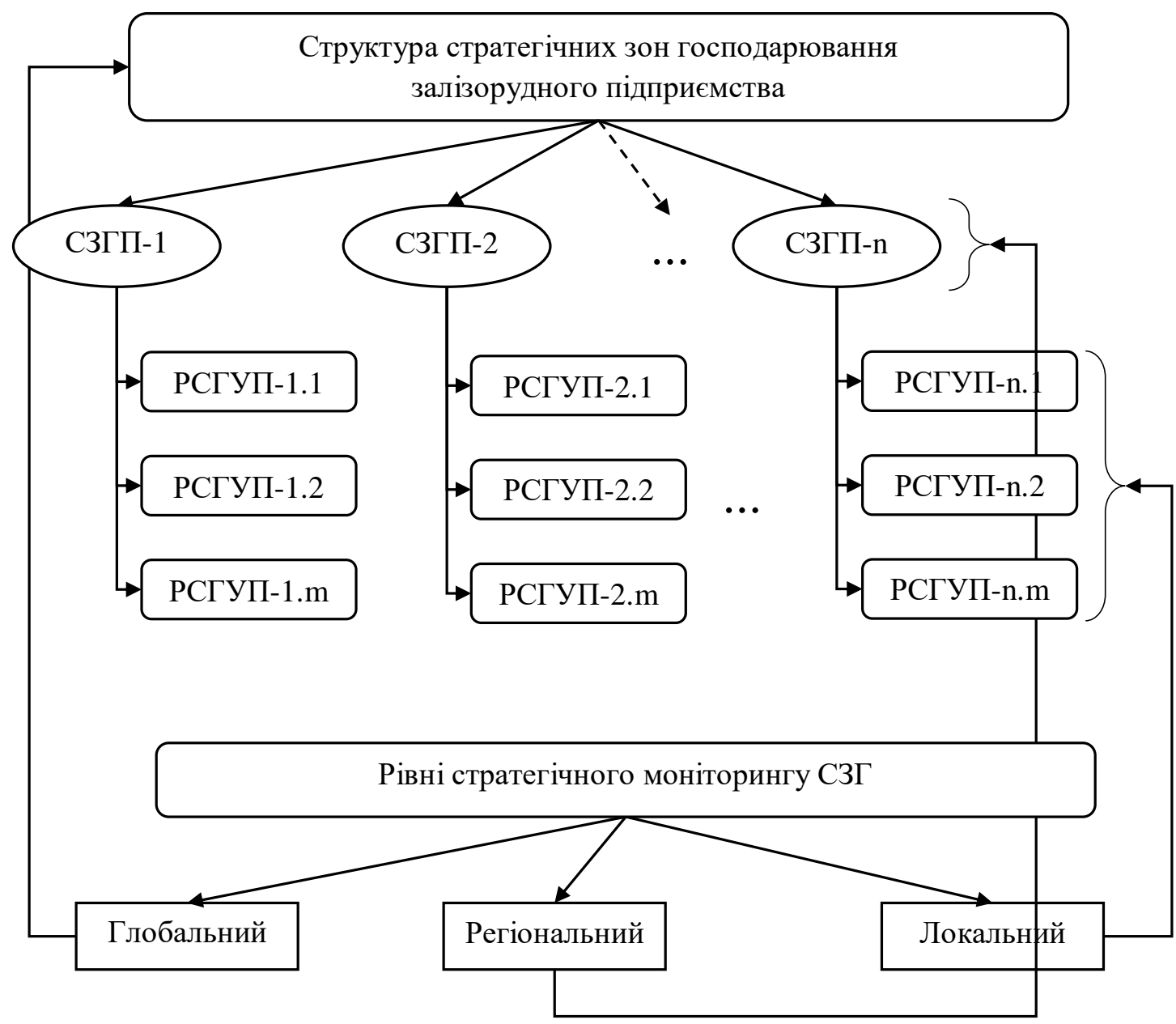

Рис. 2. Узагальнена схема системи моніторингу ситуачій в стратегічних зонах господарювання залізорудного підприємства

Система моніторингу ситуацій в стратегічних зонах господарювання залізорудного підприємства дозволяє вирішувати кардинальні питання щодо довгострокового прогнозування 3 урахуванням коригування стратегічних цілей і шляхів їх досягнення в області модернізації, технічного переозброєння, реконструкції, реінжинірингу, реорганізації, реформування, реструктуризації підприємства орієнтованих на перспективу. Основними завданнями у цій області є такі:

1) дослідження ключових проблем стосовно забезпечення гнучкого розвитку залізорудного підприємства;

2) діагностика поточного періоду діяльності залізорудного підприємства в стратегічних зонах господарювання; 
3) постановка i коригування довгострокових цілей, прийняття рішень на основі моніторингу ситуацій в СЗГ та довгострокових прогнозів і планів;

4) формування витрат і використання різноманітних видів ресурсів.

Отже, завдання довгострокових планів залізорудного підприємства повинні розроблятися на основі аналізу ситуацій в стратегічних зонах господарювання. При цьому, на першому етапі визначаються бажані рівні зростання показників i прогнозуються результати діяльності підприємства виходячи 3 різних передумов. Далі визначається планова політика, що дозволяє встановити відповідні рівні і напрямки зміни попиту та пропозиції на залізорудну продукцію, здійснюється сегментація потенційних ринків підприємства та розраховуються базові завдання.

Розвинуті теоретико-методологічні основи та методичні підходи моделювання й прогнозування дозволяють полегшити досягнення логічної завершеності ієрархії цілей і завдань довгострокового планування, проранжувати їх за принципом пріоритетності, зокрема, у такій узагальненій послідовності: базові цілі - цілі продуктово-ринкових стратегій - цілі щодо структури або ресурсів - завдання щодо рівня продуктивності [4, с. 161-162]. При цьому, базові цілі і завдання щодо моделі гнучкості залізорудного підприємства слід розділити на три підгрупи:

1) основні межі розвитку (обсяги продажу; валовий прибуток, чистий прибуток (в тому числі прибуток на оновлення); рентабельність продажів, активів, власних коштів; оборотність активів);

2) розвиток на ринку (нововведення за типами товарів; фактори, що описують стан товару на ринку (в тому числі за типами товарів), і їх тимчасові характеристики);

3) розвиток всередині залізорудного підприємства (ступінь відповідності здатності залізорудного підприємства до оновлення вимогам зовнішнього середовища (в тому числі за групами планування); тимчасові характеристики і ресурси за типами залізорудної продукції.

Напрями подальших досліджень повинні полягати в розробленні науково-методичних підходів щодо формування цілей з високим рівнем їх реалістичності. Згідно зазначеного, цілі залізорудного підприємства повинні бути реально описані, мати реальне наповнення i значення, 3 яких визначається поведінка та внутрішня філософія залізорудного підприємства. Залежно від того, на якому рівні організаційної структури виникає базова ідея, де розглядаються плани і хто їх виконує, процес планування на залізорудному підприємстві повинен здійснюватися за однією з наступних схем: від низу до верху (децентралізовано), зверху вниз (централізовано) і інтерактивно (у взаємодії).

\section{ЛIТЕРАТУРА}

1. Афанасьєв, Є.В., Афанасьєва, М.Г. (2016). Соціально-економічний та технічний розвиток підприємств: проблеми, рішення, оцінка ефективності: монографія / за заг. ред. Л.М. Савчук. Дніпропетровськ: Пороги, 2016. 553 с. / Математичне моделювання в контексті державної підтримки стратегї економічного розвитку залізорудних підприємств Украӥни. 403-413.

2. Кохана, Т. (2013). Стратегічний підхід до сегментації ринку. Аграрна економіка, (6, № 3-4), 64-69.

3. Капітула, С. В. (2018). Сучасні проблеми фінансового забезпечення кадрового потенціалу підприємств ГМК України. Збірник наукових прац̧ь" Сучасні підходи до управління підприємством", (3), 160-168.

4. Самочкин, В. Н. (2000). Гибкое развитие предприятия: Анализ и планирование. 2-е изд., испр. и доп. М.: Дело, 2000. 376 с. 